УДК 32:321:328(575.4)

https://doi.org/10.34142/24130060.2019.19.2.09

\title{
КЛАНИ ТУРКМЕНІСТАНУ: ІСТОРИКО-ПОЛІТИЧНИЙ АСПЕКТ (продовження)
}

\author{
М.Ю. Онацький \\ Харківський національний університет імені В.Н. Каразіна
}

Досліджуються роль та місие кланових інститутів у системі органів влади та управління Туркменістану. Проаналізовано особливості міжкланових відносин у Туркменістані в пострадянський період. Встановлено, щз в період президентства Г. Бердимухамедова кадрова політика в країні набула яскраво вираженого регіонального забарвлення. Це призвело до суттєвого посилення позицій етноплемінної групи ахальських текінців в державних структурах Туркменістану (як на республіканському, так $i$ на місиевому рівнях). Показано, що одним із важливих елементів кланової системи сучасного Туркменістану є т. зв. президентська «родина», вплив якої постійно зростає. Визначено роль інституту президентських радників у політичній системі краӥни.

Ключові слова: Туркменістан, політична система, кланові інститути, кадрова політика, ахальські текінці, інститут президентських радників.

\section{ОСОБЕННОСТИ КЛАНОВОГО ВЛИЯНИЯ НА ПОЛИТИЧЕСКУЮ СИСТЕМУ ПОСТСОВЕТСТКОГО ТУРКМЕНИСТАНА (ПроДОЛжеНИе)}

\section{М.Ю. Онацкий}

Исследуются роль и место клановых институтов в системе органов власти и управления Туркменистана. Проанализированы особенности межклановых отнотений в Туркменистане в постсоветский период. Установлено, что в период президентства Г.Бердымухамедова кадровая политика в стране приобрела ярко выраженную региональную окраску. Это привело к существенному усилению позищий этноплеменной группь ахальских текинцев в государственных структурах Туркменистана (как на республиканском, так и на местном уровнях). Показано, что одним из важных элементов клановой системы современного Туркменистана является т. н. президентская «семья», влияние которой постоянно возрастает. Определена роль института президентских советников в политической системе страны.

Ключевые слова: Туркменистан, политическая система, клановые институты, кадровая политика, ахальские текинщь, институт президентских советников.

\section{PECULIARITIES OF CLANE INFLUENCE ON THE POLITICAL SYSTEM OF THE POST-SOVIET TURKMENISTAN (continuation)}

\section{M.Y. Onatskiy}

The role and place of clan institutions in the system of government and administration of Turkmenistan is investigated. The features of inter-clan relations in Turkmenistan in the postSoviet period are analyzed. It was established that during the presidency of $G$. Berdymukhamedov, the personnel policy in the country acquired a pronounced regional 
coloring. This led to a significant strengthening of the position of the ethnic tribal group of Akhal Tekinians in the state structures of Turkmenistan (both at the republican and local levels). It is shown that one of the important elements of the clan system of modern Turkmenistan is the socalled. presidential "family", whose influence is constantly growing. The role of the institution of presidential advisers in the political system of the country is determined.

It is alleged that the presence of three dozen tribes, grouped into several tribal groups, each with its own habitat, as well as some conservatism inherent in the Turkmen population, led to a low level of ethnopolitical and social consolidation in Turkmen society. It is revealed that one of the important elements of the political system of Turkmenistan is the Institute of Presidential Advisers. Among them, representatives of foreign business structures who are interested in developing business relations with Turkmenistan and at the same time advocating interests of the Turkmen leadership abroad play an important role. It was found that under the conditions of formally equal representation of all regions (one nomination from each of the 6 regions), the Tekin velayats actually received a threefold advantage. Significantly increasing the chances of victory for the Tekhnik candidates (including the pro-imperious G. Berdimuhamedov) also has a significant quantitative predominance of the Tekhniks, whose number is about half the population of Turkmenistan. It is revealed that a separate group of presidential advisers is made up of officials of Russian origin who have worked for a long time in the structure of the apparatus (administration) of the president.

Key words: Turkmenistan, political system, clan institutions, personnel policy, Akhal Tekins, institute of presidential advisers.

\section{Виклад основного матеріалу (продовження). Специфічною рисою} внутрішньополітичного розвитку Туркменістану в 1990-х - на початку 2000х рр. стало те, що в цей період на владному Олімпі країни (на відміну від решти країн центральноазіатського регіону) не відбулось формування кланово-ієрархічної структури, безпосередньо пов’язаної 3 президентом. Ніязовим узами кровної спорідненості. Найближчі родичі майбутнього Туркменбаші загинули в роки війни та під час землетрусу 1948 р., його дружина та донька відмовились повертатись до Туркменістану, досить суперечливий характер мали відносини першого президента й 3 єдиним сином Мурадом. Відсутність так званої президентської «родини», як впливового неформального об’єднання, створювало для С. Ніязова певний простір для маневрування в процесі прийняття ним тих чи інших внутрішньополітичних рішень, а також значно посилювало його роль в якості арбітра в міжклановому протистоянні (Бор, 2016; Дубнов, 2017).

В умовах концентрації владних повноважень в руках ахальських текінців формування опозиційних сил відбувалось переважно в середовищі нетекінських етнорегіональних структур. Політичні партії та рухи, які 
знаходяться в опозиції до провладної Демократичної партії Туркменістану (та, здебільшого, перебувають на нелегальному становищі) мають переважно регіональну локалізацію. Так, опозиційний рух "Ватан" був представлений, головним чином, вихідцями з північного Туркменістану. В Республіканській партії переважали представники південних регіонів країни. У середині 1990-х рр. відбулась спроба відродження Комуністичної партії Туркменістану. Ініціатива в цьому питанні належала представникам західних туркмен - йомутів, які традиційно виступають за надання їх регіону широких автономних прав. Серед відомих опозиційних діячів значну кількість також складають представники переферійних кланів (у тому числі й колишні високопосадовці). Зокрема - ташаузець Худайберди Оразов, йомут Халмурад Есенов та ін. Показовим є той факт, що серед фігурантів гучної справи про замах на президента С. Ніязова (25 листопада 2002 р.) представники нетекінських земляцтв за різними даними складали від 37 до 70\% (переважно вихідці з Лебапського велаяту). Чимало їх і серед засуджених за реілігійний екстремізм. Так, за даними міжнародних правозахисних організацій, серед громадян Туркменістану, які звинувачені в релігійному екстремізмі, нетекінці складають близько 60\%. (Кадыров, 2003; Калишевский, 2014; «Покажите их живыми!», 2017, с. 5-30, 31-38).

Смерть С. Ніязова наприкінці 2006 р. символізувала завершення цілої епохи в новітній історії Туркменістану. Одним із головних наслідків зміни влади яка відбулась у республіці наприкінці 2006 - на початку 2007 pp. стало те, що політичній еліті Туркменістану, яка була представлена переважно ахальськими текінцями, вдалося не лише зберегти, але й посилити свій вплив у країні. При цьому, сам процес переходу влади (який відбувся в 2007 р. у формі президентських виборів) супроводжувався застосуванням різних політичних технологій, що мали унеможливити прихід до влади в Туркменістані представників нетекінських етнорегіональних об’єднань. Показовим, зокрема, є той факт, що з-поміж 6 претендентів на найвищу державну посаду одразу три 
кандидати представляли саме текінські області країни, в той час як від нетекінських велаятів було зареєстровано по одному представнику (Кадыров, 2007, с. 43-44).

Таким чином, навіть за умов формально рівного представництва всіх регіонів (одна кандидатура від кожної з 6 областей) текінські велаяти фактично отримували трикратну перевагу. Суттєво збільшувало шанси на перемогу кандидатів-текінців (зокрема й провладного Г. Бердимухамедова) також значна кількісна перевага текінців, чисельність яких складає близько половини населення Туркменістану.

Період президентства Г. Бердимухамедова позначений подальшим посиленням процесу «ахалізації» державного апарату Туркменістану. На сучасному етапі ахальські текінці складають майже три чверті державних службовців (Грозин, 2010, с. 51). Так, станом на 2019 р. щонайменше 11 членів Кабінету міністрів країни є вихідцями зі столичної області, а з 10 віце-прем’єрів - 6 є уродженцями Ашгабаду та Ахальської області. Розширилось представництво ахальців і на регіональному рівні. Так, із чотирьох хокимів (губернаторів) Дашоузького велаяту, які обіймали цю посаду за часів президентства Г. Бердимухамедова, троє були текінцями. При цьому, слід зважати на відсутність біографічних довідок про багатьох туркменських високопосадовців. Зокрема, маємо інформаційні дані лише про 28 з 50 міністрів уряду. Майже повністю відсутні біографічні дані, які стосуються керівників хокиматів.

Вплив текнців посилився й у силових структурах Туркменістану. За даними дослідників текінське походження мають близько 9/10 посадовців силових відомств республіки (Грозин, 2010, с. 51). На сучасному етапі ахальці очолюють МВС, МНБ, Міністерство оборони, Генеральну прокуратуру. Показовим є, зокрема, той факт, що з владного Олімпу було усунуто чи не єдиного впливового високопосадовця нетекінського походження, колишнього керівника служби безпеки С. Ніязова генерала А. Реджепова (хоча саме його підтримка мала вирішальне значення в 
процесі обрання на посаду президента Г. Бердимухамедова), а також його протеже, міністра національної безпеки, Гельдимухаммед Аширмухаммедова (теж представника переферійного клану). Швидка відставка, а згодом й арешт колишнього керівника служби безпеки президента С. Ніязова стали наслідком у тому числі й відсутності в оточенні А. Реджепова земляків-одноплемінників, які потенційно могли б надати своєму покровителю політичну підтримку. Даний епізод $є$ досить показовим, оскільки певним чином демонструє роль патрон-клієнтних зв’язків у сучасному туркменському суспільстві (Планета. Беларусь и мир).

Варто зазначити, що за часів другого президента кадрова політика набула яскраво вираженого регіонального забарвлення: в процесі здійснення посадових призначень перевага надається передусім тим текінцям, які проживають у західних районах Ахальського велаяту. Це, певним чином, контрастує з політикою С. Ніязова, який утримувався від призначень на державні посади своїх земляків. Помітну роль у політичному житті держави почало відігравати близьке оточення президента Г. Бердимухамедова, до якого увійшло чимало членів його родини. Під контролем президентської «сім’ї», яка налічує близько 80 осіб, опинились усі найбільш прибуткові галузі економіки Туркменістану, а сама «родина» поступово перетворилась на головний осередок прийняття найважливіших рішень у країні (Бор, 2016, с. 29-30; 7, с. 51; Дубнов, 2017; Бульвінський ред., 2017, с. 217).

Домінування ахальців у центральних органах влади Туркменістану певним чином обумовило й специфіку соціально-економічного розвитку країни та окремих її регіонів. Так, фактично в привілейованому положенні опинився столичний Ахальський велаят. Проявом цього є, зокрема, той факт, що саме на території Ашгабаду та Ахальського велаяту розташовано понад 40\% усіх виробничих закладів країни, а також абсолютна більшість (85\%) підприємств в яких задіяний іноземний капітал. Беззаперечним лідером столична область виступає також і за кількістю територіальних 
одиниць, які включені до складу вільних економічних зон (Кадыров, 2004, с. 30).

Водночас, концентрація економічних важелів у руках ахальської еліти спостерігається не лише в Ахальському велаяті, але й у нетекінських регіонах. Зокрема, мова йде про прикаспійські райони республіки (Балканський велаят). У радянський період та в роки незалежності представники даної племінної групи відігравали помітну роль в управлінні експортними галузями економіки Туркменістану (нафтовою та газовою). Втім, за часів президентства Г. Бердимухамедова їх позиції були певною мірою ослаблені. Цьому сприяли як численні кадрові ротації в регіоні, так і переведення офісу національної нафтовидобувної компанії «Туркменнафта» 3 Балканабату до столиці. Скоротився й економічний вплив марийських текінців, що багато в чому стало наслідком арешту мультимільйонера та колишнього посадовця П. Мередова (який вважався лідером даного клану). Загалом же, каральна політика в Туркменістані досить яскраво ілюструє клановий підхід. Так, за даними міжнародних правозахисних організацій, серед осіб, які в роки незалежності були засуджені за економічні злочини та перевищення службових повноважень, щонайменше 65\% - представники неахальських регіонів (Бор, 2016, с. 29; Голубев, 2010, с. 568, 576; Горак, 2007, с. 73; «Покажите их живыми!», c. 39-54).

Одним із небагатьох елементів політичної системи Туркменістану, який безпосередньо не пов'язаний з клановими структурами, став інститут президентських радників. На відміну від урядових посад, які обіймають виключно етнічні туркмени, президентськими радниками нерідко стають представники нетуркменського походження - росіяни, євреї, турки, французи тощо. Серед них варто виділити передусім представників великих закордонних приватних компаній, які працюють у Туркменістані. Фактично вони виступають довіреними особами туркменського президента та виконують посередницькі функції в стосунках вищого керівництва 
Туркменістану 3 діловими колами іноземних держав. Показовим $\epsilon$, зокрема, той факт, що президент С. Ніязов зазвичай особисто проводив переговори з іноземними партнерами. Етнічні ж туркмени з оточення президента приймали участь у таких зустрічах досить рідко (Бор 2016, c. 30; Горак, 2007, с. 66; Минченко, 2011, с. 40).

3-поміж представників іноземних бізнес-структур, які користувались довірою першого президента Туркменії варто назвати керівника корпорації «Merhav», ізраїльського мільярдера Й. Мемана. Компанія «Merhav», що спеціалізується на реалізації проектів у галузі нафто- та газоенергетики, протягом тривалого часу виступає незмінним партнером туркменського уряду, допомагаючи розвивати стосунки 3 країнами західного світу. Радником Туркменбаші вважють також і керівника французької компанії «Bouygues Batiment International» Мартена Буіга, про ступінь впливу якого свідчить той факт, що саме його бізнес-структура отримувала (i продовжила отримувати вже в період президентства Г. Бердимухамедова) всі великі замовлення на здійснення будівельних робіт у Туркменістані (Минченко, 2011, с. 40-41).

Деякі іноземні бізнес-партнери за часів С. Ніязова одночасно обіймали й впливові державні посади, що свдчить про високий ступінь довіри до них з боку туркменського керівництва, а також вказує на важливість розбудови стосунків з тими країнами, яких ці підприємці представляли. Так, турецький бізнесмен Ахмет Чалик, який представляв інтереси Туркменістану в країнах близькосхідного регіону, деякий час був заступником міністра легкої промисловості. Віце-президент російської компанії «Ітера» Валерій Отчерцов у період президентства С. Ніязова обіймав посаду віце-прем'єра туркменського уряду. В 1990-х - на початку 2000-х рр. компанія «Ітера» виступала в ролі медіатора газових схем, а самого В. Отчерцова називають одним із лобістів інтересів Туркменії в Росії та Україні (Минченко, 2011, с. 40-42). 
Великим іноземним компаніям, які закріпились на туркменському ринку в роки президентства С. Ніязова, у переважній більшості вдалося зберегти свої позиції й після приходу до влади нового очільника країни. Про це свідчить той факт, що уряд Г. Бердимухамедова продовжує співпрацювати з тими іноземними бізнес-структурами, з якими працював його попередник. Певним виключенням стала компанія А. Чалика, вплив якого після смерті Туркменбаші відчутно скоротився. Натомість, посилились позиції іншої турецької корпорації «Polimeks Insaat», яка задіяна в будівництві інфраструктурних проектів. IІЇ власник, бізнесмен Ероль Табанджи, на думку деяких експертів, також був одним із радників президента С. Ніязова. Саме діяльність на туркменському ринку будівельних компаній «Polimeks Insaat» та «Bouygues Batiment International» вважається найбільш успішною, що багато в чому можна пояснити дружніми стосунками власників цих підприємств 3 керівництвом Туркменістану (Горак, 2007, с. 66; Минченко, 2011, с. 39-41).

Окрему групу президентських радників складають посадовці російського походження, які протягом тривалого часу працювали в структурі апарату (адміністрації) президента. Не дивлячись на численні кадрові ротації вони продовжували лишатись на своїх посадах протягом усього періоду перебування при владі С. Ніязова та зберегли свій вплив за часів його наступника. Серед них - Володимир Умнов та колишній заступник керівника апарату президента Олександр Жадан, які відповідали за економічні питання. Ще один президентський радник - Віктор Храмов тривалий час опікувався ідеологічними питаннями (зокрема, діяльністю туркменських видавництв). Вважається, що саме він був відповідальним за формування культу першого та другого президентів Туркменістану. На відміну від етнічних туркмен (як текінців, так і вихідців із регіонів) нетуркмени не мають потужної політичної підтримки всередині країни. Відтак, вони не представляють для керівництва Туркменістану будь-якої серйозної небезпеки та змушені зберігати лояльність діючій владі. Саме 
цим пояснюється їх тривале перебування на державних посадах (Бор, 2016, с. 30 ; Горак, 2007 , с. 66,76 ; Федеров, 2007, с. 96).

Висновки і перспективи подальших досліджень. Таким чином, клановість залишається одним із ключових чинників суспільнополітичного розвитку Туркменістану. Наявність трьох десятків племен, об’єднаних у кілька племінних груп, кожна 3 яких мала свій ареал проживання, а також певний консерватизм, що притаманний населенню Туркменії, зумовили низький рівень етнополітичної та соціальної консолідації туркменського суспільства.

Об’єднання в межах утвореної в 1924 - 1925 рр. Туркменської СРР кількох регіонів, на території яких традиційно кочували туркменські громади, сприяло формуванню певної етнічної конфігурації, коли одна племінна група - текінці - отримала значну кількісну перевагу над усіма іншими. Саме текінці займали керівні посади республіканського рівня в 1920-х - 1940-х pр. У повоєнний період радянська кадрова політика в Туркменістані зазнала певних коректив, i на високі посади почали призначатись переважно вихідці 3 регіональних кланів. При цьому, 3 метою унеможливити політичну гегемонію з боку представників якоїсь однієї племінної групи, радянсько-партійне керівництво розробило відповідну систему заміщення керівних посад у центральних органах влади Туркменії.

Друга половина 1980-х - початок 2000-х pp. позначились посиленням політичного впливу текінців, що було пов’язано 3 перебуванням на чолі республіки ахальського текінця С. Ніязова. Втім, цей процес не набув усеохоплюючого масштабу. Попри те, що більшість посадовців були етнічними текінцями, на високі державні посади в цей період не рідко призначались також і вихідці з регіонів. Подібна практика була спрямована на збереження певного етнополітичного балансу в центральних органах влади. Водночас, вона стала відображенням міжкланового суперництва в боротьбі за політичний вплив у країні: 
позиціонуючи себе в якості політичного арбітра президент Туркменістану, в такий спосіб, фактично протиставляв одні кланові угрупування іншим, не дозволяючи при цьому надмірно зміцнити свої позиції жодному з них.

У період президентства Г. Бердимухамедова відбулось посилення процесу «ахалізації» державного апарату Туркменії. Вже за кілька років після обрання на посаду нового очільника країни переважну більшість держслужбовців та керівників силових структур склали вихідці 3 Ахальського велаяту. Суттєву роль у політичному житті Туркменістану почала відігравати так звана президентська «сім'я» - близьке оточення Г. Бердимухамедова, яке пов'язане з ним узами кровної спорідненості. Це різко контрастує з періодом президентства С. Ніязова, для якого ключову роль у процесі призначення на високі посади відігравала особиста відданість, а не родинні зв'язки.

Одним із важливих елементів політичної системи Туркменістану виступає інститут президентських радників. Серед них важливу роль відіграють представники іноземних бізнес-структур, які зацікавлені в розвитку ділових відносин з Туркменістаном та одночасно виступають лобістами інтересів туркменського керівництва закордоном. Ще одна група радників представлена співробітниками апарату президента (росіянами за походженням). Вони не пов'язані 3 існуючими в Туркменістані етнополітичними угрупуваннями та опікуються передусім питаннями економічного та ідеологічного характеру. Втім, їх функціональні обов'язки, як і сфера їхнього реального впливу потребують подальшого уточнення.

\section{ЛITEРАТУРА}

1. Бор, А., 2016. Туркменистан: власть, политика и петро-авторитаризм. [online] Доступн: https://www.chathamhouse.org/sites/default/files/publications/research/201603-08-turkmenistan-bohr-russian.pdf [Дата обращения 23 Август 2019].

2. Бульвінського, А. Г. ред., 2017. Особливості суспільно-політичної модернізаиії країн пострадянського простору: монографія. Київ: ДУ «Інститут всесвітньої історії НАН України». 
file://C:/Users/Admin/Downloads/Monografia_modernizacij_2017_.pdf зверенення 03 Сентябрь 2019].

3. Голубев, С. 2010. Очерки политической истории стран «ближнего зарубежья»: республики бывшего СССР в 1989 - 2009 гг. Тверь: Ариадна.

4. Горак, С., 2007. Туркменистан после Туркменбаши: к вопросу трансформации режимов личной власти. Политическая экспертиза: ПОЛИТЭКС, [online] 3 (3), с. 62-78. Доступно: https://cyberleninka.ru/article/n/turkmenistan-posleturkmenbashi-k-voprosu-o-transformatsii-rezhimov-lichnoy-vlasti [Дата обращения 27 Август 2019].

5. Грозин, А. А., 2010. Элиты Туркменистана и центральноазиатские кланы: общее, особенное и трудности модернизации. Азия и Африка сегодня, 9, с. 50-51.

6. Дубнов, А., 2017. 10 лет без Туркменбаши. Как изменилась Туркмения за годы без диктатора. [online] (Останнє оновлення 12 Январь 2017) Доступно: https://aurora.network/articles/165-interv-ju/29027-10-let-bez-turkmenbashi-kakizmenilas-turkmenija-za-gody-bez-diktatora [Дата обращения 27 Август 2019].

7. Кадыров, Ш., 2004. Становление и эволющия этнополитической организации у туркмен. Кандидат наук. Центр цивилизационных и региональных исследований Института Африки РАН. [online] Доступно: https://newdisser.ru/_avtoreferats/01002638294.pdf [Дата обращения 03 Сентябрь 2019].

8. Кадыров, Ш., 2005. Этнология управления в Средней Азии: вчера, сегодня, завтра. [online] (Останне оновлення 6 Июнь 2005) Доступно: http://www.igpi.ru/bibl/other_articl/1119947605.html [Дата обращения 27 Август 2019].

9. Кадыров, Ш., 2007. Туркмения: Дворцовый переворот. Азия и Африка сегодня, 4, c. 41-45.

10. Калишевский, М., 2014. Туркменистан: Оппозищия в тисках "башизма", [online] 25 Март. Доступно: http://www.cisnews.org/news/tm/7763-oppoziciya-v-tiskahbashizma.html [Дата обращения 03 Сентябрь 2019].

11. Минченко, Е. и Петров, К., 2011. Инвестициионный потенцииал Туркменистана. Анализ политических рисков. [online] Доступно: http://www.stratagema.org/netcat_files/File/Last_Rus_sm.pdf [Дата обращения 03 Сентябрь 2019].

12. Общественно-политический журнал Планета, 2007. Капкан для генерала Реджепова. [online] Доступно: https://planeta.by/article/211 [Дата обращения 03 Сентябрь 2019].

13. «Покажите их живыми!», 2017. Список исчезнувших в тюрьмах Туркменистана. [online] Международная правозащитная кампания «Покажите их живыми!». Доступно: https://www.osce.org/ru/odihr/346146?download=true [Дата обращения 03 Сентябрь 2019]

14. Федеров, Ю., 2007. Туркмения: время перемен? Индекс безопасности, [online] 3-4 (90-91), Т. 15, с. http://www.pircenter.org/kosdata/page_doc/p2643_1.pdf [Дата обращения 03 Сентябрь 2019].

\section{Інформація про автора}

Онацький Максим Юрійович - кандидат історичних наук, доцент кафедри туристичного бізнесу та країнознавства Харківського національного університету імені B.H. Каразіна; e-mail: onatskij@karazin.ua ORCID: http://orcid.org/0000-0002-6733-6137

Стаття надійшла до редакції: 10.10.2019 р. $\quad$ Прийнята до друку: 29.10.2019 p. 